\title{
Uptake of zinc and cadmium by two populations of shore crabs Carcinus maenas at different salinities
}

\author{
Hing Man Chan ${ }^{1, *}$, Poul Bjerregaard ${ }^{2}$, Philip S. Rainbow ${ }^{1}$, Michael H. Depledge ${ }^{2}$ \\ ${ }^{1}$ School of Biological Sciences, Queen Mary and Westfield College, University of London, Mile End Road, \\ London E1 4NS, United Kingdom \\ ${ }^{2}$ Institute of Biology, Odense University, Campusvej 55, DK-5320 Odense M, Denmark
}

\begin{abstract}
Effects of salinity on the accumulation of $\mathrm{Zn}$ and $\mathrm{Cd}$ in the haemolymph (relative indices of $\mathrm{Zn}$ and $\mathrm{Cd}$ uptake rates) of 2 populations of shore crab Carcinus maenas (L.) were investigated. $\mathrm{Zn}$ accumulation rates in the haemolymph of the Scottish (high salinity) crabs were higher than those of the Danish (low salinity) crabs. Decreases in salinity significantly decreased the $\mathrm{Zn}$ accumulation rate in the Scottish crabs but increases in salinity did not change the $\mathrm{Zn}$ accumulation rates in the Danish crabs significantly. Scottish crabs also showed a higher $\mathrm{Cd}$ accumulation rate, as well as elimination rate, than those of the Danish crabs. The highest Cd accumulation rate in Scottish crabs was found at $33 \mathrm{ppt}$ salinity. In contrast the $\mathrm{Cd}$ accumulation rate of Danish crabs was highest at $15 \mathrm{ppt}$. It is proposed that exposure of the crabs to low salinity probably involves changes to crab permeability (e.g. apparent water permeability), thereby off-setting physico-chemical changes promoting the availabilities of free zinc and cadmium ions in solution which would otherwise increase metal uptake rates.
\end{abstract}

\section{INTRODUCTION}

Decreases in salinity are associated with increased uptake rates (and potentially increased body burdens and toxicity) of zinc and cadmium in marine crustaceans (O'Hara 1973a, b, Hutcheson 1974, Wright 1977a, Nugegoda \& Rainbow 1989a, b). This is thought to occur because at low salinities free metal ion concentrations increase as chloride complexation decreases (Zirino \& Yamamoto 1972, Mantoura et al. 1978). Free metal ions have been identified as the principal chemical species bioavailable to organisms [taken up either via facilitated diffusion and/or, in the case of cadmium, possibly by active transport (Depledge \& Rainbow 1990)]. Thus bioavailability and hence uptake of the metais are enhanced (see Simkiss \& Taylor 1989). However, in some of the more resilient euryhaline crustaceans, for example the shore crab Carcinus maenas (L.), there is a possibility that physiological adaptation to dilute media may not only help to

\footnotetext{
- Present address: Department of Pathology, The University of Western Ontario, London, Ontario, Canada N6A 5C1
}

minimise ionic and osmotic fluxes, but also impair the uptake of dissolved trace metals (Depledge 1990).

The present study was carried out to assess the relative importance of changes in chemical speciation and physiological adaptation in determining uptake rates of zinc and cadmium in Carcinus maenas. Crabs from 2 populations were used; one from a high salinity environment on the Atlantic coast of Scotland, the other from a low salinity environment in the southern Kattegat. It was decided to compare the rates of accumulation of labelled $\mathrm{Zn}$ and $\mathrm{Cd}$ in the haemolymph of Scottish and Danish crabs at different salinities. This approach has the advantage of being able to monitor the $\mathrm{Zn}$ and $\mathrm{Cd}$ uptake rates of each crab. The rates of $\mathrm{Zn}$ and $\mathrm{Cd}$ accumulation in the haemolymph are a measure of the relative rates of $\mathrm{Zn}$ and $\mathrm{Cd}$ uptake in the crab only if the $\mathrm{Zn}$ and $\mathrm{Cd}$ unloading rates from the haemolymph are the same among crabs at different salinities. This assumption is tested by a second experiment measuring the unloading rate by injecting radioactively labelled $\mathrm{Zn}$ and $\mathrm{Cd}$ into the crabs and monitoring their rates of decrease in the haemolymph of crabs in seawater of various salinities 


\section{MATERIALS AND METHODS}

Rate of $\mathrm{Zn}$ and Cd accumulation in haemolymph with respect to salinity. Shore crabs Carcinus maenas were collected during summer 1989 from 2 populations; (1) on the northern coast of the island of Fyn, Denmark, and (2) around the Isle of Cumbrae, Firth of Clyde, Scotland. During the period of collection, the salinity was in the range 10 to $20 \%$ and 26 to $33 \%$ in Denmark and Scotland respectively. Temperature at both locations was between 10 to $15^{\circ} \mathrm{C}$. Crab fresh weights varied from 61 to $101 \mathrm{~g}$ (mean $\pm 1 \mathrm{SD}$ : $87 \pm 16 \mathrm{~g}$ ) for Danish crabs, and from 33 to $114 \mathrm{~g}$ $(79 \pm 29 \mathrm{~g})$ for Scottish crabs. Any effect of crab size on results was checked (see 'Results').

Replicate samples of Danish and Scottish crabs were exposed to the following regimes: (1) $15 \%$, (2) $25 \%$ and (3) $33 \%$. Eight crabs (in 2 groups of 4 ) from each population were assigned to 2 replicate tanks containing Danish local coastal water made up to one of the above salinities with added artificial seawater (TMN) or by dilution, and pre-exposed for $5 \mathrm{~d}$. Thus the Danish crabs at $15 \%$ and the Scottish crabs at $33 \%$ were pre-exposed essentially to their habitat salinities but crabs in other salinities would be in a process of acclimation to the new salinities. These latter exposures would provide information on uptake effects of acclimation [potentially incomplete initially (5 d) but progressing for a further $7 \mathrm{~d}$ ] on uptake rates for comparison with uptake rates for the 2 original populations in their habitat salinities.

At the start of the experiment, the water was changed and each tank was dosed with $50 \mu \mathrm{g}^{-1}$ total $\mathrm{Zn}$ and $4.4 \mu \mathrm{Ci}^{-1}{ }^{65} \mathrm{Zn}$, and $0.13 \mu \mathrm{g} \mathrm{l}^{-1}$ total $\mathrm{Cd}$ and $0.9 \mu \mathrm{Ci} l^{-1}{ }^{109} \mathrm{Cd}$. Concurrently, 2 additional tanks were set up to provide data on the progress of acclimation of transferred crabs, 1 with 4 crabs from the Danish population (in $33 \%$ salinity seawater), the other with 4 crabs from the Scottish population (in $15 \%$ salinity seawater), again with the same $5 \mathrm{~d}$ preexposure as appropriate. $\mathrm{Zn}$ and $\mathrm{Cd}$ were not added to these tanks. Crabs were held under the above conditions for an experimental period of $7 \mathrm{~d}$ at $15^{\circ} \mathrm{C}$. All. crabs were starved during the pre-exposure and experimental periods. Dissolved concentrations of ${ }^{65} \mathrm{Zn}$ and ${ }^{109} \mathrm{Cd}$ were monitored daily and adjusted as needed to maintain a constant activity. Haemolymph samples $(0.5 \mathrm{ml}$ each) were taken from each crab initially (Day 0), after $12 \mathrm{~h}$, and then on Days 1, 2, 3, 4, and 7. Labelled $\mathrm{Zn}$ and $\mathrm{Cd}$ concentrations in the haemolymph samples were measured by gamma scintillation counting using an LKB 1282 Compugamma Universal Gamma Counter.

Blood osmolality and protein concentrations of crabs in tanks without added $\mathrm{Zn}$ or $\mathrm{Cd}$ are affected by salin- ity changes, and therefore were also measured during the $7 \mathrm{~d}$ experimental period, as described by Bjerregaard \& Vislie (1986).

$\mathrm{Zn}$ and $\mathrm{Cd}$ unloading: estimation of blood volume. Six crabs from both populations were exposed to either 7 or $33 \%$ for $5 \mathrm{~d}$. A further 6 Danish crabs were exposed to a salinity regime of $15 \%$. Each crab was then injected with $10 \mu \mathrm{l}$ solution containing $1.1 \mu \mathrm{g}$ total $\mathrm{Zn}$ and $0.62 \mu \mathrm{Ci}{ }^{65} \mathrm{Zn}, 8 \mathrm{ng}$ total $\mathrm{Cd}$ and $0.05 \mu \mathrm{Ci}{ }^{109} \mathrm{Cd}$. Haemolymph samples $(0.5 \mathrm{ml}$ each) were collected from each crab at $0.5,2,10.5$ and $24 \mathrm{~h}$ after injection. Labelled $\mathrm{Zn}$ and Cd concentrations in the haemolymph samples were measured. Readings taken at $0.5 \mathrm{~h}$ were used as the initial reference concentrations.

The injection of a radioactive tracer in a minute volume (insignificant compared to total blood volume) also allows a good approximation of total blood volume. For example, injected radioactive zinc is removed from the blood (see 'Results') to the tissues (Chan 1990) at a constant rate. Blood concentrations of radioactive zinc can then be measured at time intervals. Back extrapolation of the blood concentration of radioactive zinc to time 0 gives an estimate of the initial radioactive zinc concentration in the blood, and hence blood volume. This is not a standard method of measuring blood volume but, with knowledge of the assumptions made, it does provide estimates in good agreement with the literature (Depledge 1989).

\section{RESULTS}

Mortalities of the Danish and Scottish Carcinus maenas exposed to different salinities during the $7 \mathrm{~d}$ experimental period were never greater than 2 out of 8 crabs. There was no significant correlation between crab mortality and the exposure salinity. Results from crabs in the 2 replicate tanks for each group and each salinity regime showed no significant differences. Therefore, the results from the crabs in the 2 replicate tanks were pooled for analysis. Moreover, for ease of statistical comparison, only results obtained from 6 crabs (randomly chosen) in each population and salinity regime were used for analysis.

Labelled $\mathrm{Zn}$ concentrations in the haemolymph of Danish and Scottish crabs are shown in Fig. 1. In all cases accumulation of zinc increased with time according to an approximately linear relationship (results of best fit tests showed a highest $\mathrm{r}^{2}$ value for the linear equation). No correlation was observed between $\mathrm{Zn}$ accumulation and the body weight of the crabs, so accumulated concentrations have not been expressed on a body weight basis. Linear regression statistics are also shown in Fig. 1 where the slope (b) reflects the rate of zinc accumulation in the haemolymph. 
The rates of accumulation differed significantly between crabs from the 2 populations of crabs and among different exposure conditions. The Scottish crabs exhibited significantly faster accumulation than Danish crabs when compared at 33 and $25 \%$ ( $p<0.01$, $\mathrm{df}=10)$ (Fig. 1a to $\mathrm{d})$. The accumulation rate $(b)$ of $\mathrm{Zn}$ in Scottish crabs exposed to $25 \%$ was significantly lower ( $\mathrm{p}<$ $0.01, \mathrm{df}=10$ ) than that in Scottish crabs at $33 \%$ (Fig. 1c, d), and in turn was significantly higher than the $\mathrm{Zn}$ accumulation rate in Scottish crabs exposed to $15 \%$ ( $p<0.05$, df = 10; Fig. 1f). The $\mathrm{Zn}$ accumulation rate in Scottish crabs exposed to $15 \%$ was not significantly different from any one of those of the Danish crabs exposed to the 3 salinities. No significant difference in accumulation rate was observed among the Danish crabs exposed to the 3 different salinities (Fig. 1a, c \& e).

Table 1 shows the accumulated labelled $\mathrm{Zn}$ concentrations and $\mathrm{Zn}$ contents in the crab haemolymph after the $7 \mathrm{~d}$ experiment. The newly acquired labelled $\mathrm{Zn}$ concentrations in the haemolymph are very low in all cases. The labelled $\mathrm{Zn}$ concentrations ranged from 78 to $268 \mathrm{ng} \mathrm{ml}^{-1}$ which account for only 0.21 to $0.89 \%$ of total $\mathrm{Zn}$ concentrations in the crab haemolymph. As expected from Fig. 1, the haemolymph of Scottish crabs exposed to $33 \%$ had a significantly higher labelled Zn concentration than that of Danish crabs exposed to the same salinity $(p<0.05, \mathrm{df}=10)$. No significant difference was observed between the labelled $\mathrm{Zn}$ concentrations of the 2 crab populations in the remaining 2 salinities. The labelled Zn concentrations in the Scottish crabs however seem to show a higher degree of variation (SD) than those of Danish crabs.

The haemolymph volumes of 30 Carcinus maenas of the 2 populations were estimated by injecting a known amount of labelled $\mathrm{Zn}$ into the crabs. The changes in the average percentages of initial injected labelled $\mathrm{Zn}_{\mathrm{n}}$ remaining in the crab haemolymph over the $24 \mathrm{~h}$ experimental period are presented in Fig. 2. Back extrapolation to time 0 allowed estimation of the haemolymph volume which was found to constitute approximately $20 \%$ of the total wet weight of the crabs, in good agreement with published values (Depledge 1989). The total accumulated labelled $\mathrm{Zn}$ content was also esti-

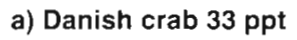

$y=-9.2+16.5 \times \quad r=0.90^{*}$ $y=16.5 \pm 0.9$
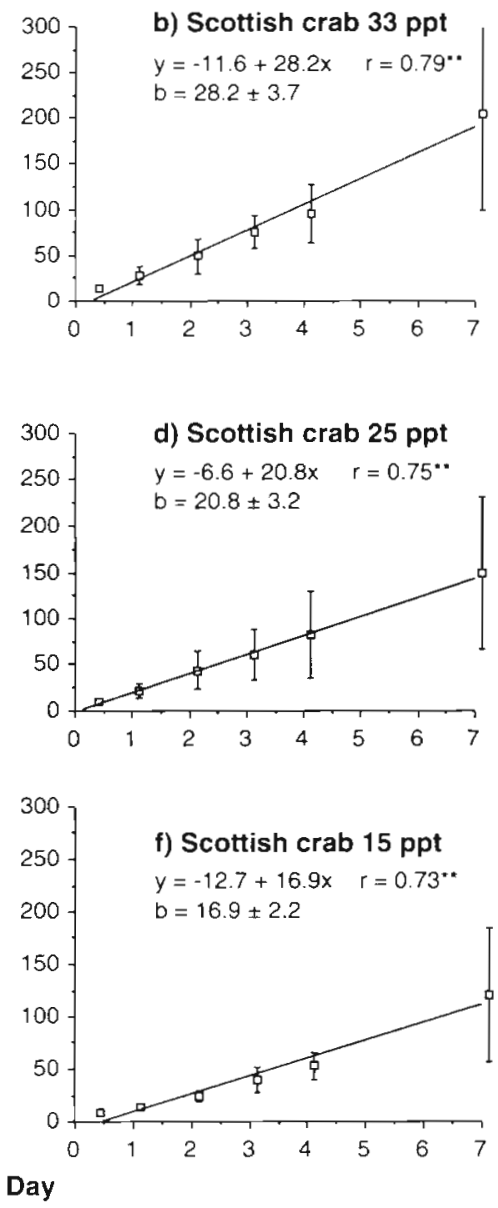

Day

Fig. 1 Carcinus maenas. Labelled $\mathrm{Zn}$ concentrations in haemolymph over $7 \mathrm{~d}$ exposure in $50 \mu \mathrm{g} \mathrm{Zn} 1^{-1}$ media for: (a) Danish and (b) Scottish crabs at $33 \%$ salinity; (c) Danish and (d) Scottish crabs at $25 \%$; (e) Danish and (f) Scottish crabs at $15 \%$. Mean $\pm 1 \mathrm{SD}$. Where no error bars are shown, SD is within the point plotted mated using this value. Crabs from both populations accumulated less than $5 \mu \mathrm{g}$ of labelled $\mathrm{Zn}$ in their haemolymph following $7 \mathrm{~d}$ exposure to $50 \mu \mathrm{g}$ labelled $\mathrm{Zn} \mathrm{l^{-1 }}$. The Scottish crabs exposed to $33 \%$ accumulated significantly higher levels of labelled $\mathrm{Zn}$ than individ-

Table 1. Carcinus maenas. Labelled $\mathrm{Zn}$ concentrations and contents (mean $\pm 1 \mathrm{SD}$ ) in the haemolymph of Scottish and Danish crabs, maintained at different salinities for the $? d$ experimental period

\begin{tabular}{|lcc|}
\hline $\begin{array}{l}\text { Populations and } \\
\text { exposure salinities }\end{array}$ & $\begin{array}{c}\text { Labelled Zn conc. } \\
\text { (ng ml }\end{array}$ & $\begin{array}{l}\text { Labelled } \mathrm{Zn} \\
\text { content }(\mu \mathrm{g})\end{array}$ \\
\hline Danish crabs $(33 \%)$ & $111 \pm 22.3$ & $1.94 \pm 0.29$ \\
Scottish crabs $(33 \%$ ) & $196 \pm 66.2$ & $3.07 \pm 1.15$ \\
Danish crabs $(25 \%)$ & $107 \pm 36.0$ & $1.76 \pm 0.65$ \\
Scottish crabs $(25 \%)$ & $141 \pm 72.2$ & $2.23 \pm 1.23$ \\
Danish crabs $(15 \%)$ & $110 \pm 37.9$ & $1.89 \pm 0.72$ \\
Scottish crabs $(15 \%)$ & $114 \pm 70.3$ & $2.28 \pm 1.53$ \\
\hline
\end{tabular}



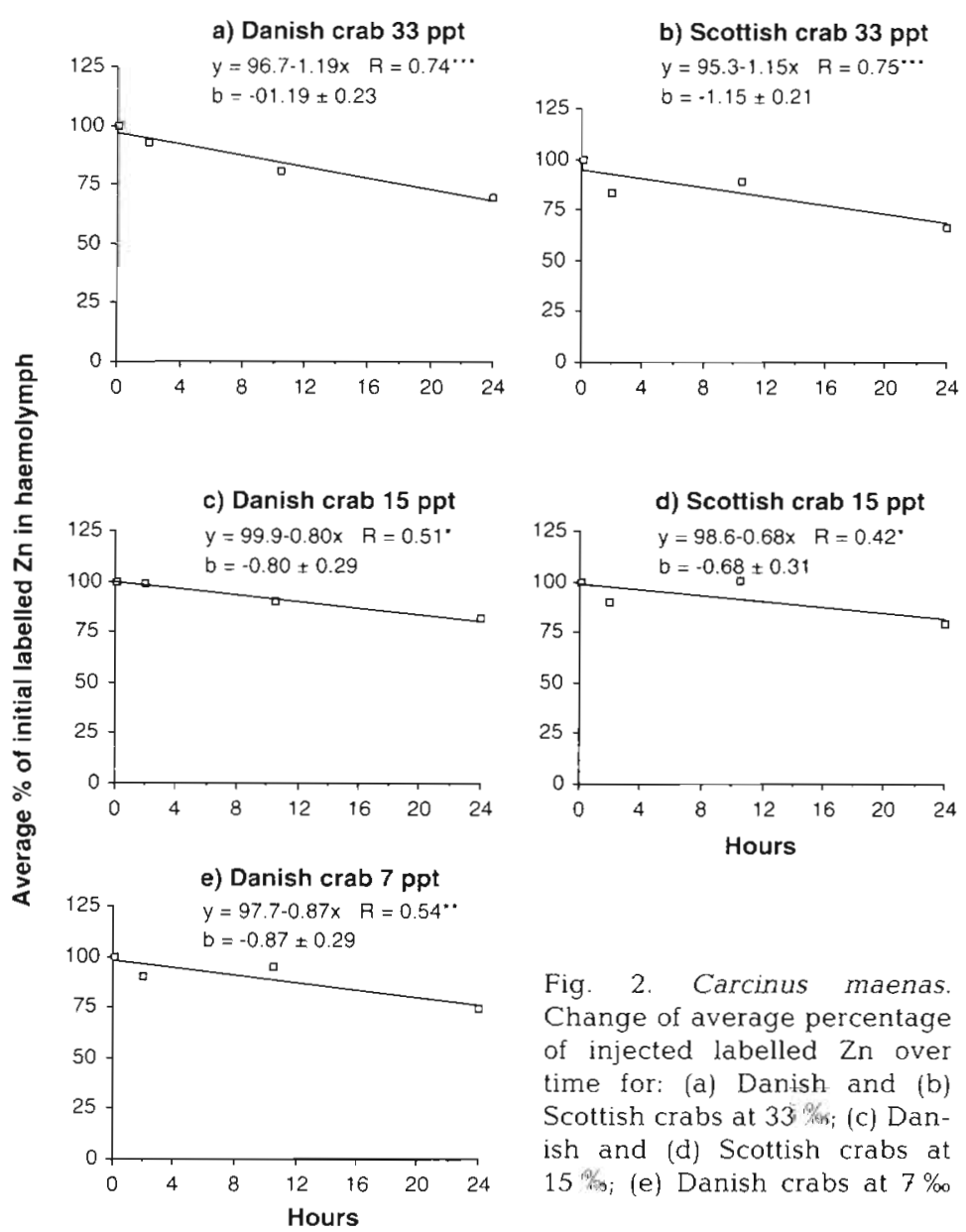

Fig. 2. Carcinus maenas. Change of average percentage of injected labelled $\mathrm{Zn}$ over time for: (a) Danish and (b) Scottish crabs at $33 \%$; (c) Danish and (d) Scottish crabs at $15 \%$; (e) Danish crabs at $7 \%$

$3 a$ to $d)$. The mean accumulation rate (b) of $\mathrm{Cd}$ in Scottish crabs exposed to $33 \%$ was significantly higher than in Scottish crabs at both 25 and $15 \%$ (Fig. 3b, d \& f). The Cd accumulation rate in Danish crabs exposed to $15 \%$ was significantly higher $(p<0.05$, $\mathrm{df}=10$ ) than in those crabs exposed to 33 and $25 \%$ (Fig. 3a, c \& e).

Unlike $\mathrm{Zn}$, over $75 \%$ of the injected $\mathrm{Cd}$ was lost from the haemolymph after $24 \mathrm{~h}$ (Fig. 4). Moreover, the best fit regression describing loss was an exponential relationship, so that highest elimination rates were recorded in the first few hours after injection. The rates of $\mathrm{Cd}$ loss ( $b$ in Fig. 4 ) were higher in Scottish crabs than in Danish crabs. Cd was removed from the haemolymph with a half life of approximately $8 \mathrm{~h}$ and $12 \mathrm{~h}$ in Scottish and Danish crabs respectively. No intra-group (i.e. within the Danish crabs or the Scottish crabs) differences in elimination rate occurred with change in salinity.

The osmolalities and protein concentrations of the haemolymph collected from the crabs not exposed to $\mathrm{Zn}$ or $\mathrm{Cd}$ (Scottish crabs in $15 \%$ and Danish crabs in $33 \%$ ) during the $7 \mathrm{~d}$ experimental period are shown in Table 2. Since the crabs from both populations had been acclimated to the experimental salinities $5 \mathrm{~d}$ prior to the beginning of the experiment, their haemolymph ion and protein concentrations were already significantly

uals in the other 2 salinities and, in turn, higher levels than the Danish crabs at all 3 salinities.

The regression statistics and the rates of decrease $(b)$ of injected labelled $\mathrm{Zn}$ concentration over time are also presented in Fig. 2. All the crabs retained over $75 \%$ of the injected labelled $\mathrm{Zn}$ in their haemolymph. No significant differences were observed among rates of decrease (unloading rates from the haemolymph into the tissues) in the crabs from the 2 populations and among salinity regimes. It was therefore not necessary to make differential corrections to the net accumulation rates shown in Fig. 1 in order to obtain relative uptake rates.

Haemolymph concentrations of labelled $\mathrm{Cd}$ in crabs from the 2 populations exposed in the 3 salinity regimes over $7 \mathrm{~d}$ are presented in Fig. 3. In all cases Cd accumulated over time according to an approximately linear relationship (results of the best fit tests showed a highest $r^{2}$ value for the linear equation).

The rates of accumulation (b) differ significantly between crabs from the 2 populations. Scottish crabs exhibited significantly greater $\mathrm{Cd}$ accumulation rates than Danish crabs at 33 and $25 \%(\mathrm{p}<0.01$, df $=10)$ (Fig. different from those of crabs from native populations. The osmolalities of the haemolymph of Scottish crabs sampled during this experiment were significantly lower $(p<0.001, \mathrm{df}=8$ ) than that of the native population (1058 $\pm 10.6 \mathrm{mOsm} \mathrm{kg}{ }^{-1}$; Chan unpubl. data). However, there was a slight increase in osmolality over the experimental period and the osmolality of the Scottish crabs haemolymph collected at Day 7 was significantly higher than that collected after $12 \mathrm{~h}(\mathrm{p}<0.01, \mathrm{df}=10)$. The osmolalities of Danish crab haemolymph collected in this experiment were all significantly higher $(p<0.01$, $\mathrm{df}=10)$ than those of the native crabs $(775 \pm 21.8 \mathrm{mOsm}$ $\mathrm{kg}^{-1}$; Chan unpubl. data). There was a continuous increase in osmolality of the Danish crab haemolymph over the experimental period and the osmolality at Day 7 was significantly higher than that at $12 \mathrm{~h}(\mathrm{p}<0.001$, $\mathrm{df}=10)$.

The protein concentrations in the Danish crab haemolymph were significantly higher than those of the Scottish crabs $(\mathrm{p}<0.05$, df $=10)$. The haemolymph of both crab populations showed a significant decrease in protein concentrations with time. This was probably a result of repeated sampling from the crabs 

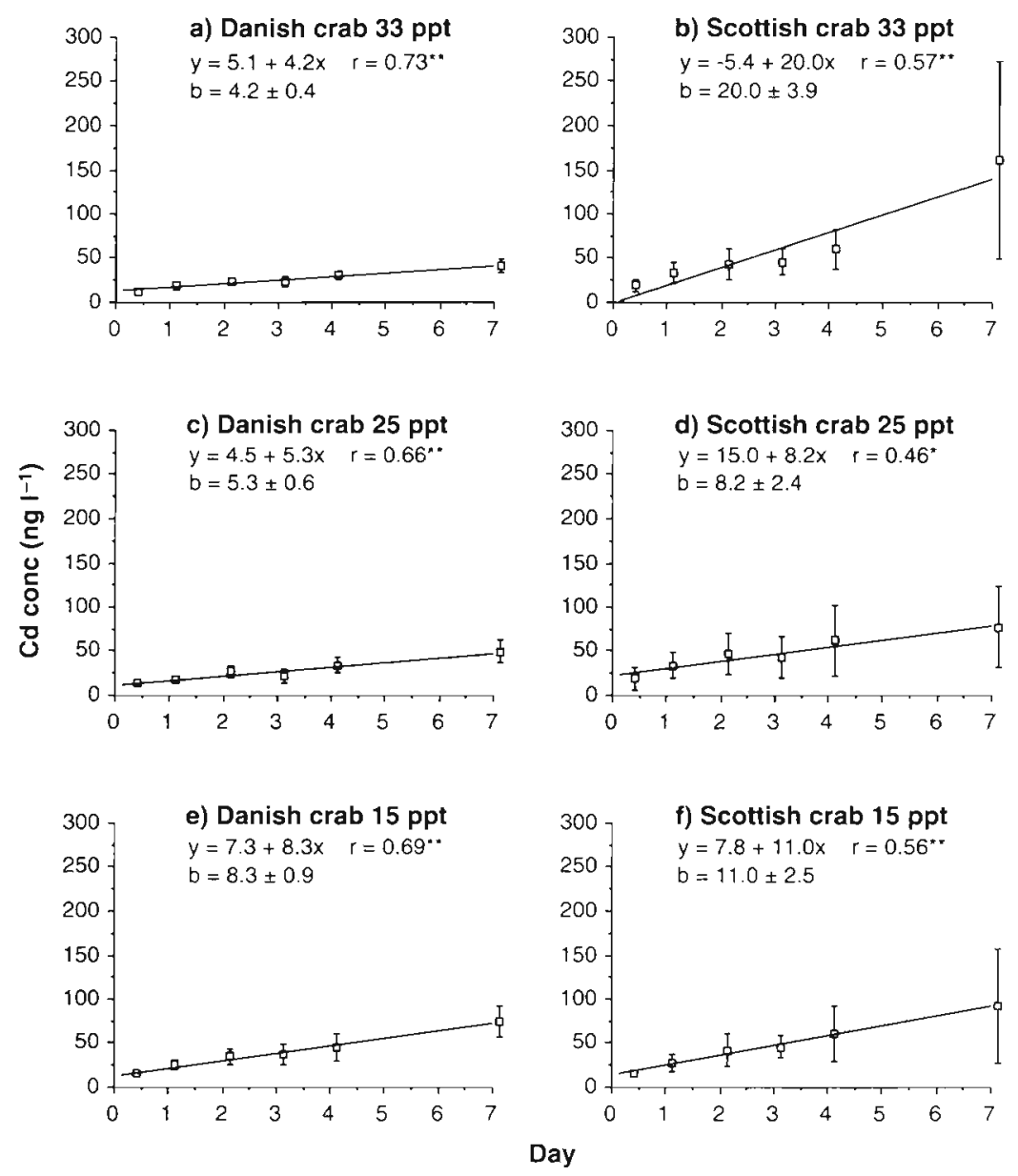

Fig. 3. Carcinus maenas. Labelled Cd concentrations in haemolymph over $7 \mathrm{~d}$ exposure in $0.13 \mu \mathrm{g} \mathrm{Cd} \mathrm{l}^{-1}$ media for: (a) Danish and (b) Scottish crabs at $33 \%$; (c) Danish and (d) Scottish crabs at $25 \%$; (e) Danish and (f) Scottish crabs at $15 \%$. Mean $\pm 1 \mathrm{SD}$. Where no error bars are shown, SD is within the point plotted

\section{DISCUSSION}

The rates of $\mathrm{Zn}$ accumulation in the haemolymph of Carcinus maenas measured in this study can be regarded as relative indices of the rates of $\mathrm{Zn}$ uptake into crabs, as the $\mathrm{Zn}$ (percentage) unloading rate from the haemolymph into tissues did not differ significantly among crabs from either populations at any of the experimental salinities.

The labelled Zn uptake experiment revealed a significantly higher Zn uptake rate in Scottish crabs from high salinity (33\%) water, than in Danish crabs from low salinity (15 to $25 \%$ ) waters. In an interspecific comparative study, Nugegoda \& Rainbow (1989a) similarly found that Palaemonetes varians from low salinities exhibited significantly lower $\mathrm{Zn}$ uptake rates than Palaemon elegans typically from higher salinity regions, when compared under the same conditions in the laboratory.
In contrast to the earlier findings of Nugegoda \& Rainbow (1989a) where Zn uptake rate in Palaemon elegans was found to increase with decreasing salinity, $\mathrm{Zn}$ uptake rate in Carcinus maenas did not. Indeed, in individuals from the Scottish population $\mathrm{Zn}$ uptake actually decreased significantly as salinity was lowered. Danish crabs showed the same trend although the uptake rates were not statistically significantly different. There is compelling evidence both from other experimental studies (e.g. Sunda et al. 1978, Engel \& Fowler 1979, Jenkins \& Sanders 1986, Nugegoda \& Rainbow $1989 a, b)$ and from physico-chemical analyses and theory (Mantoura et al. 1978) that $\mathrm{Zn}$ and $\mathrm{Cd}$ bioavailabilities increase in dilute seawater.

How then can the present findings be interpreted? Depledge (1990) suggested that many euryhaline invertebrates are able to survive in brackish waters by virtue of welldeveloped physiological control systems and that such systems might also confer some degree of protection against exposure to trace metals by limiting uptake. It seems likely that this might well involve changes in apparent water permeability (AWP) and apparent electrolyte permeability (AEP). Smith (1970) has shown that Northumberland (North Sea; highsalinity adapted) individuals of this species decrease water permeability with decreasing salinity below $75 \%$ seawater. Similarly, electrolyte permeability also decreases at low salinities (Spaargaren 1974, 1975), perhaps in association with changes in potential difference across the gill (Siebers et al. 1989). Given the phenotypic nature of such changes in AWP and AEP, populations with different histories of salinity exposure will show different physiological responses to salinity change. It is plausible therefore that the Scottish population exhibited a progressive adaptation in AWP and AEP with decreasing salinity that also decreased the permeability of the crabs to $\mathrm{Zn}$. Thus, although $\mathrm{Zn}$ bioavailability increases with decline in salinity, the crabs became increasingly impermeable to $\mathrm{Zn}$ to such an extent that overall uptake of $\mathrm{Zn}$ fell.

The Danish crabs have developed in, and are adapted to, the low salinity environment of the southern Kattegat. As predicted from the above model they 


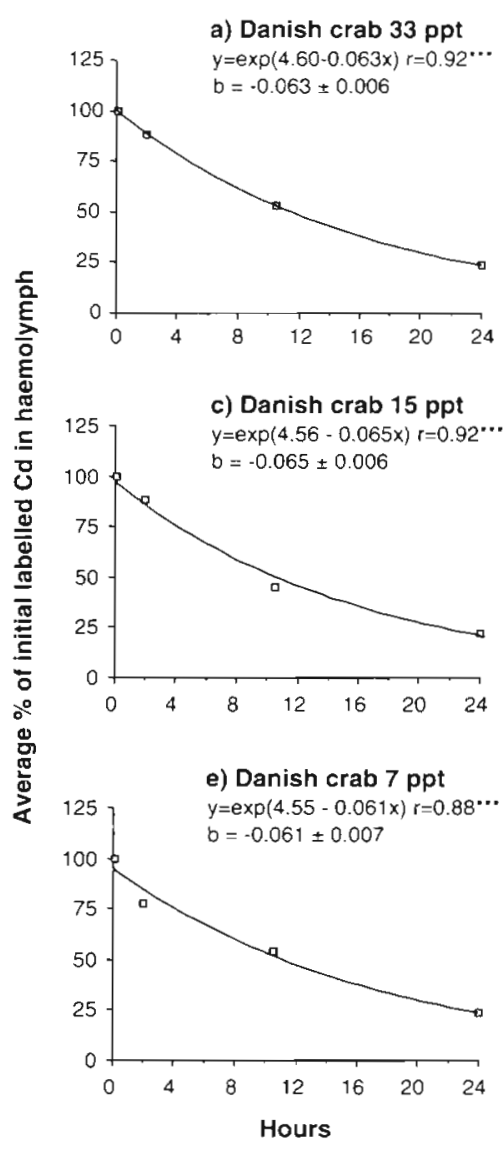

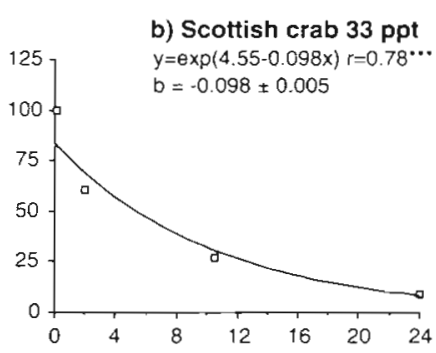

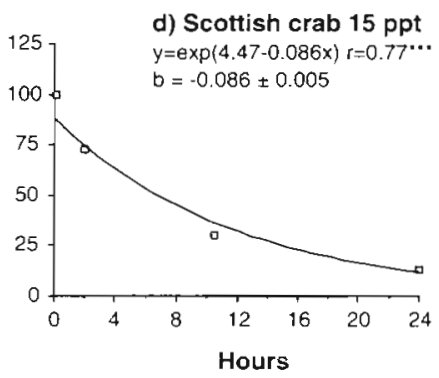

Fig. 4. Carcinus maenas. Change of average percentage of injected labelled $\mathrm{Cd}$ over time for (a) Danish and (b) Scottish crabs at $33 \%$; (c) Danish and (d) Scottish crabs at $15 \%$; (e) Danish crabs at $7 \%$
Any change in permeability to water, electrolytes and trace metal ions should also be apparent in the data from the Cd uptake experiments. A caveat is necessary here. $\mathrm{Cd}$ was found to be quickly eliminated from the haemolymph, probably to the midgut gland (Wright 1977b, Bjerregaard 1990), and there was a difference between the percentage elimination rates of $\mathrm{Cd}$ from the haemolymph of Danish and Scottish crabs. However, percentage elimination rates of $\mathrm{Cd}$ from the haemolymph did not differ within the 2 population groups, irrespective of salinity; so it is valid to use haemolymph $\mathrm{Cd}$ accumulation rates as relative measures of Cd uptake when comparing within the groups of Scottish and Danish crabs.

The Cd results are entirely consistent with the $\mathrm{Zn}$ results discussed above. In the case of the Scottish crabs, individuals in $33 \%$ seawater once again displayed the highest metal uptake rates, whilst crabs in 25 and $15 \%$ had lower uptake rates that did not differ significantly from one another (although the value in $15 \%$ was higher). As with $\mathrm{Zn}$, the bioavailability of $\mathrm{Cd}$ increases as salinity falls due to reduced chloride ion complexation. However, the percentage increase in free $\mathrm{Cd}$ ion concentration for a given salinity

have lower Zn uptake rates than the Scottish crabs. Reversal of the induced changes in AWP, AEP and $\mathrm{Zn}$ permeability by transfer of the Danish crabs to higher salinities was not evident during the experimental period. Since such processes are probably under hormonal control, longer term acclimation is probably required for this to occur (see Berlind \& Kamemoto 1977). The Danish crabs may have reached the limit of the physiological response of changing permeabilities, but in any case, the increases in $\mathrm{Zn}$ bioavailability were small and were masked by inter-individual variability in uptake rates among the crabs. drop is much greater than for Zn (Zirino \& Yamamoto 1972, Mantoura et al. 1978). Thus, it appears that any reductions in AWP and AEP at $25 \%$ are sufficient to limit $\mathrm{Cd}$ uptake despite greater bioavailability of $\mathrm{Cd}$. At $15 \%$, Cd bioavailability has increased proportionately more so that uptake is slightly enhanced in the creased Cd uptake progressively with decreased salinity (significantly between 25 and $15 \%$ ) in such a way as to reflect the relatively strong increases in $\mathrm{Cd}$ bioavailability. Presumably permeability to $\mathrm{Cd}$ in Danish crabs is already low in $33 \%$ seawater and canface of reduced permeability. The Danish crabs in-

Table 2. Carcinus maenas. Blood osmolalities and protein concentrations (mean \pm 1 SD) of Scottish crabs in $15 \%$ and Danish crabs in $33 \%$ salinity during the $7 \mathrm{~d}$ experiment

\begin{tabular}{|c|c|c|c|c|}
\hline \multirow[t]{2}{*}{ Day } & \multicolumn{2}{|c|}{ Osmolality (mOsm kg $\mathrm{kg}^{-1}$ ) } & \multicolumn{2}{|c|}{ Protein conc. $\left(\mathrm{mg} \mathrm{ml}^{-1}\right)$} \\
\hline & $\begin{array}{c}\text { Danish crabs } \\
33 \%\end{array}$ & $\begin{array}{c}\text { Scottish crabs } \\
15 \%\end{array}$ & $\begin{array}{c}\text { Danish crabs } \\
30 \%\end{array}$ & $\begin{array}{c}\text { Scottish crabs } \\
15 \%\end{array}$ \\
\hline 0.5 & $833 \pm 65.6$ & $583 \pm 20.6$ & $58.1 \pm 11.7$ & $38.2 \pm 4.31$ \\
\hline 1 & $836 \pm 43.3$ & $593 \pm 52.5$ & $53.6 \pm 11.3$ & $3.9 \pm 4.59$ \\
\hline 2 & $843 \pm 23.6$ & $586 \pm 67.3$ & $49.8 \pm 16.7$ & $38.1 \pm 7.74$ \\
\hline 3 & $928 \pm 25.3$ & $671 \pm 54.1$ & $52.7 \pm 12.1$ & $34.1 \pm 5.40$ \\
\hline 4 & $973 \pm 49.4$ & $660 \pm 86.6$ & $49.9 \pm 8.96$ & $33.0 \pm 4.59$ \\
\hline 7 & $1020 \pm 34.4$ & $740 \pm 56.6$ & $45.2 \pm 12.7$ & $33.5 \pm 5.26$ \\
\hline
\end{tabular}


not be reduced further at lower salinities. Here again, the stronger effects of changes in Cd speciation overcome the competing physiological adaptation of changes in AWP and AEP.

The interpretation given above is consistent with the available data and implies that, in Carcinus maenas at least, physiological adaptive responses may play a more important role in determining trace metal uptake rates than do changes in chemical speciation with reductions in salinity. The $\mathrm{Zn}$ uptake rates of Palaemon elegans did not show such responses to reduced salinity (Nugegoda \& Rainbow 1989a), indicating that in this decapod any change in water and electrolyte permeability that might occur, cannot compensate for the increased metal bioavailability at low salinities. Indeed, Campbell \& Jones (1990) have shown that AWP in $P$. elegans is relatively high compared with permeabilities in other estuarine crustaceans, with no significant change in AWP between 34 and $12 \%$ (at $12^{\circ} \mathrm{C}$ ).

Wright (1977a) investigated the effects of salinity on $\mathrm{Cd}$ accumulation in the haemolymph of Cd-exposed Northumberland Carcinus maenas. His results are consistent with those reported here. At a $\mathrm{Cd}$ exposure

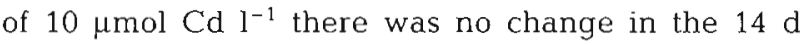
accumulated $\mathrm{Cd}$ concentration in the haemolymph of crabs at salinities between between 100 and $50 \%$ seawater. A significant rise in uptake only became apparent after dilution to $40 \%$ seawater (Fig. 1 of Wright 1977 a).

The results of this study highlight interspecific differences in the factors affecting trace metal uptake by euryhaline crustaceans, the relative importance of physico-chemical and physiological responses varying, for example between Carcinus maenas and Palaemon elegans. These results thus bear out the conclusion of Depledge (1990) that physiological adaptations of euryhaline crustaceans to dilute media have the potential to play an important role in determining trace metal uptake and accumulation.

\section{LITERATURE CITED}

Berlind, A., Kamemoto, F. I. (1977). Rapid water permeability changes in eyestalkless euryhaline crabs and in isolated perfused gills. Comp. Biochem. Physiol. 58A: 383-385

Bjerregaard, P. (1990). Influence of physiological condition on cadmium transport from haemolymph to hepatopancreas in Carcinus maenas. Mar. Biol. 106: 199-209

Bjerregaard, P., Vislie, T. (1986). Effect of copper on ion- and osmoregulation in the shore crab Carcinus maenas. Mar. Biol. 91: 69-76

Campbell, R. J., Jones, M. B. (1990). Water permeability of Palaemon longirostris and other euryhaline caridean prawns. J. exp. Biol. 150: 145-158

Chan, H. M., (1990). Aspects of the biology of zinc in crabs with particular emphasis on the shore crab Carcinus maenas (L.). Ph.D thesis, University of London
Depledge, M. H. (1989). Re-evaluation of metabolic requirements for copper and zinc in decapod crustaceans. Mar. environ. Res. 27: 115-126

Depledge, M. H. (1990). Interactions between heavy metals and physiological processes in estuarine invertebrates. In: Chambers, P. L., Chambers, C. M. (eds.) Estuarine ecotoxicology. JAPAGA, Ashford, Ireland, p. $89-100$

Depledge, M. H., Rainbow, P. S. (1990). Models of regulation and accumulation of trace metals in marine invertebrates. Comp. Biochem. Physiol. 97 C: 1-7

Engel, D. W., Fowler, B. A. (1979). Factors affecting cadmium accumulation and its toxicity to marine organisms. Environ. Hith Perspect. 28: 81-88

Hutcheson, M. S. (1974). The effect of temperature and salinity on cadmium uptake by the blue crab Callinectes sapidus. Chesapeake Sci. 15: 237-241

Jenkins, K. D., Sanders, B. M. (1986). Relationships between free cadmium ion activity in seawater, cadmium accumulation and subcellular distribution, and growth in polychaetes. Environ. Hlth Perspect. 65: 205-210

Mantoura, R. F. C., Dickson, A., Riley, J. P. (1978). The complexation of metals with humic materials in natural waters. Estuar. coast. mar. Sci. 6: 387-408

Nugegoda, D., Rainbow, P. S. (1989a). Effects of salinity changes on zinc uptake and regulation by the decapod crustaceans Palaemon elegans and Palaemonetes varians. Mar. Ecol. Prog. Ser. 51: 57-75

Nugegoda, D., Rainbow, P. S. (1989b). Salinity, osmolality, and zinc uptake in Palaemon elegans (Crustacea: Decapoda). Mar. Ecol. Prog. Ser. 55: 149-157

O'Hara, J. (1973a). The influence of temperature and salinity on the toxicity of cadmium to the fiddler crab, Uca pugilator. Fish Bull. U.S. 71(1):149-153

O'Hara, J. (1973b). Cadmium uptake by fiddler crabs exposed to temperature and salinity stress. J. Fish. Res. Bd Can. 30: 846-848

Siebers, D., Wille, H., Luce, C., Dalla Venezia, L. (1989). Conductive sodium entry in gill cells of the shore crab, Carcinus maenas. Mar. Biol. 101: 61-68

Simkiss, K., Taylor, M. J. (1989). Metal fluxes across the membranes of aquatic organisms. CRC crit. Rev. aquat. Sci. 1: $173-188$

Smith, R. I. (1970). The apparent water-permeability of Carcinus maenas (Crustacea, Brachyura, Portunidae) as a function of salinity. Biol. Bull. 139: 351-362

Spaargaren, D. H. (1974). A study of the adaptation of marine organisms to changing salinities with special reference to the shore crab Carcinus maenas. Comp. Biochem. Physiol. 47 A: 499-512

Spaargaren, D. H. (1975). Changes in permeability in the shore crab Carcinus maenas (L.), as a response to salinity. Comp. Biochem. Physiol. 51A: 549-552

Sunda, W. G., Engel, D. W., Thuotte, R. M. (1978). Effects on chemical speciation on the toxicity of cadmium to the grass shrimp Palaemonetes pugio: importance of free cadmium ion. Environ. Sci. Technol. 12: 409-413

Wright, D. A. (1977a). The effect of salinity on cadmium uptake by the tissues of the shore crab Carcinus maenas. J. exp. Biol. 67 : 137-146

Wright, D. A. (1977b). The uptake of cadmium into the haemolymph of the shore crab Carcinus maenas: the relationship with copper and other divalent cations. J. exp. Biol. 67 : $147-161$

Zirino, A., Yamamoto, S. (1972). A pH-dependent model for the chemical speciation of copper, zinc, cadmium and lead in seawater. Limnol. Oceanogr. 17: 661-671 